section, composed of displays from universities, research associations, hospitals, etc.; and a commercial section devoted to manufacturers' products. Altogether there will be displays from more than fifty exhibitors. In addition to an extensive programme of lectures and film shows, visits will be arranged to the University of Manchester Computing Department. Exhibition catalogues (1s. 6d. post paid), lecture and film show programmes $\left(4 \frac{1}{2} d\right.$. post, paid) and further information are available from the honorary exhibition organizing secretary, W. Birtwistle, 78 Shaw Road, Thornham, Rochdale, Lancs.

\section{Congress in Leyden of the International Society for Cell Biology}

THE eighth congress of the International Society for Cell Biology, known as the Cytology Congress, will be held in Leyden during September 1-8, under the presidency of Prof. F. Newton Harvey, of Princeton University. Full members of the Society, and candidates for membership approved by the International Committee, are automatically entitled to attend the congress and to introduce one guest. The programme of symposia, at which invited papers will be read, will include the following topics : induced enzyme synthesis; the formation of the intracellular matrix in plant and animal tissues; immunobiological concepts of cellular growth and differentiation ; biochemistry of gene action ; thyroid secretion; nuclear and chromosome structure; mitochondria; cell division and mitotic poisons; morphogenetic interactions between cells; virus synthesis; the active cell surface; and submicroscopic structure of cytoplasm. The sessions on mitochondria, nuclear and chromosome structure and submicroscopic organization of cytoplasm form a special conference on the "Fine Structure of Cells", held under the auspices of the International Union of Biological Sciences. At the general sessions members and their guests may contribute papers on topics of their own choosing, and notification should be made before July 1. Further information can be obtained from the secretary of the Congress, Dr. W. K. H. Karstens, Botanical Laboratory, Nonnensteeg 3, Leyden.

In conjunction with the congress, the National Museum for the History of Science, Steenstraat $1 \mathrm{~A}$, Leyden, is organizing an exhibition, "From Magnifying Glass to Fye of Science", to be held during June 25-September 19. The exhibits will include microscopes, demonstrations of instruments, drawings, manuscripts and portraits, etc., from the period of about 1630-1880. A catalogue will be available.

\section{Colonial Service : Recent Appointments}

THE following appointments have recently been made in the Colonial Service: J. W. Purseglove (senior agricultural officer, Uganda), director of botanical gardens, Singapore; G. D. Shaw (veterinary officer, Northern Rhodesia), chief veterinary research officer, Northern Rhodesia; B. L. Mitchell (tsetse entomologist, Nyasaland), biologist, Game and Tsetse Control Department, Northern Rhodesia; G. D. Stockwell, veterinary officer, Tanganyika; E. S. Clayton, economist/statistician, Economic Research Division, Kenya; W. S. Foster, soil survey officer, Nigeria; R. A. Smart, assistant conservator of forests, Northern Rhodesia; J. H. Smith, veterinary officer, Nigeria; T. F. Twist, meteorologist (British Caribbean Meteorological Service), Trinidad.

\section{Announcements}

Sir Harold Roxbee Cox, chief scientist of the Ministry of Fuel and Power since 1948, is resigning from the public service on June 30 , in order to take up appointments in the engineering industry.

THE Lord President of the Council has appointed Sir Hugh Beaver to be chairman of the Advisory Council for Scientific and Industrial Research in succession to Sir Ian Heilbron, who retires on September 30 on completion of his term of office. Sir Hugh Beaver, who has been a member of the Advisory Council since 1952, is managing director of Arthur Guinness, Son and Co., Ltd.

Aт the University of Cambridge on June 10, honorary degrees were conferred on the following, among others : Sc.D., Prof. P. M. S. Blackett, professor of physics at the Imperial College of Science and Technology, University of London, and Sir Charles Dodds, Courtauld professor of biochemistry in the University of London; Litt.D., Miss Gertrude Caton-Thompson, known for her work in archæology.

PRof. J. McCUNN, professor of veterinary anatomy in the Royal Veterinary College, London, has been appointed acting principal of the College in succession to the late Prof. J. B. Buxton.

Prof. P. Pruvosx, director of the Institut de la Houille, Paris, and correspondant for the Mineralogical Section of the Paris Academy of Sciences, has been elected a member of the Mineralogical Section of the Academy in succession to the late E. de Margerie.

THE following appointments have been made in the University College of North Staffordshire: Mr. A. G. N. Flew, at present lecturer in the Department of Moral Philosophy, University of Aberdeen, to be professor of philosophy; Dr. D. G. Holloway, to be assistant lecturer in physics.

Dr. C. B. B. Downman, senior lecturer at St. Thomas's Hospital Medical School, London, has been appointed to the University of London readership in physiology tenable at the Royal Free Hospital School of Medicine.

The Sports Turf Research Institute will hold a silver jubilee conference on July 1 at its St. Ives Research Station, Bingley, Yorks, in celebration of its founding in 1929. Besides the four principal lectures of the conference, facilities will be provided for inspecting the work of the Institute, and a display of machinery and equipment will be staged. Application forms for the conference, to be returned by June 25, can be obtained from the Research Station.

IT is proposed to institute a special international award, to consist of a bronze medal and a scroll, for outstanding work in the field of venereal diseases and non-venereal treponematoses, the award to be administered by the World Health Organization. It is hoped to collect enough money to make it an annual award, and interested individuals and organizations are invited to contribute to the establishment of this special fund, cheques being mado payable to "The International Treponematosis Award Fund". In Great Britain the temporary treasurer is Dr. R. R. Wilcox, of St. Mary's Hospital, London, W.2, and in the United States Dr. Frank W. Reynolds, of the Saratoga Spa, Saratoga Springs, N.Y. 